\section{Role of Ethylene and 1-MCP in Flower Development and Petal Abscission in Zonal Geraniums}

\author{
Michelle L. Jones ${ }^{1}$, Eun-Sun Kim ${ }^{2}$, and Steven E. Newman ${ }^{3}$ \\ Department of Horticulture and Landscape Architecture, Colorado State \\ University, Fort Collins, CO 80523
}

Additional index words. petal shattering, flower senescence, ethephon, Pelargonium $\times$ hortorum

\begin{abstract}
Geraniums are sensitive to ethylene during shipping and respond by abscising their petals. Treatment of stock plants with ethylene (ethephon) in order to increase cutting yield resulted in earlier flowering in Pelargonium $\times$ hortorum 'Kim' and 'Veronica', but did not result in increased susceptibility to petal abscission following exposure to $1.0 \mu \mathrm{L} \cdot \mathrm{L}^{-1}$ ethylene. Treatment of 'Kim', 'Veronica', 'Fox', and 'Cotton Candy' with $1.0 \mu L^{\prime} L^{-1}$ ethylene resulted in increased petal abscission within one hour, with 'Fox' being the most sensitive and 'Kim' the least. Pretreatment of florets with 1-MCP for 3, 6, 12, or 24 hours at concentrations of 0.1 or $1.0 \mu \mathrm{L} \cdot \mathrm{L}^{-1}$ decreased petal abscission in all cultivars following exposure to $1.0 \mu \mathrm{L} \cdot \mathrm{L}^{-1}$ ethylene. Treatment with $0.1 \mu \mathrm{L} \cdot \mathrm{L}^{-1} 1-\mathrm{MCP}$ for 1 hour reduced petal abscission rates in ethylene treated florets to that of non-ethylene treated controls in all cultivars except Fox. 'Fox' florets, which are more sensitive to ethylene, required 12 to 24 hours of exposure to 1-MCP to reduce petal abscission rates to that of control flowers. Pretreatment of geranium plants with 1-MCP can be used to reduce petal shattering during shipping. Chemical names used: 2-chloroethanephosphonic acid (ethephon); 1-methylcyclopropene (1-MCP).
\end{abstract}

Geraniums (Pelargonium $\times$ hortorum) are popular landscape plants because they flower prolifically, bloom continually, and have a wide variety of flower colors. The major postharvest problem with geraniums is petal shattering during shipping (Oglevee, 1998). Zonal geraniums are one of the most ethylene-sensitive plant species, with some cultivars abscising all of their petals after a $1 \mathrm{~h}$ exposure to 1.0 $\mu \mathrm{L} \cdot \mathrm{L}^{-1}$ ethylene (Clark et al., 1997; Evensen, 1991; Evensen et al., 1993). Ethylene sensitivity has been shown to vary between cultivars of both regal $(P . \times$ domesticum $)$ and zonal $(P$. $\times$ hortorum) geraniums, with the severity of the response to ethylene increasing with the age of the floret (Clark et al., 2001; Deneke et al., 1990).

The postharvest quality of many flowering plants is reduced by ethylene. Ethylene causes premature wilting, color fading and abscission of flower petals. Ethylene induced senescence and abscission can result from exposure to exogenous ethylene during shipping or increased endogenous ethylene production by the flower resulting from stress, wounding, pollination, or infection (Abeles et al., 1992).

Cameron and Reid (1983) demonstrated that spraying seedling geraniums with the ethylene action inhibitor, silver thiosulfate (STS), effectively prevented petal shattering during

\footnotetext{
Received for publication 31 Oct. 2000. Accepted for publication 28 Feb. 2001. We would like to thank Dan Busch of Busch Greenhouses in Denver, Colo., for supplying us with rooted geranium cuttings. This research was funded in part by the Colorado Floriculture Foundation and the Colorado Agricultural Experiment Station (project \#738).

${ }^{1}$ Assistant Professor.

${ }^{2}$ Graduate Student.

${ }^{3}$ Associate Professor.
}

shipping. While the application of STS reduced petal abscission in geraniums, it also predisposed them to Phythium root rot (Hausbeck et al., 1987). An additional drawback of spraying potted flowering plants with STS is that it has a narrow range of concentrations at which it is effective as an ethylene action inhibitor without being phytotoxic (Nell, 1993).

A new ethylene action inhibitor, 1-MCP has been developed as an alternative to STS. 1MCP has been shown to improve the postharvest quality of a number of flowering potted plants (Serek et al., 1994). It is as effective an ethylene action inhibitor as STS, but it is nontoxic to plant tissues at concentrations much higher than those needed for maximum effectiveness (Serek et al., 1994,1995; Sisler et al., 1996).

While ethylene exposure is generally detrimental to the postharvest quality of flowering plants, the ethylene treatment of stock plants is utilized to eliminate flowers in order to produce more compact plants and maintain them vegetatively. Geranium stock plants treated with ethylene in the form of the commercial growth regulator ethephon can yield as many as $20 \%$ more cuttings than non-ethephontreated plants (O'Donovan, 1993). Although this is a benefit to producers, growers in Colorado have expressed concern as to whether ethylene treatment of stock plants might predispose the flowers to increased rates of petal abscission by increasing the plants' sensitivity to ethylene.

The objectives of the research presented in this paper were 3 -fold: 1 ) to investigate whether the treatment of stock plants with ethylene has any residual effect on time to flowering or petal abscission in plants produced from cuttings of these stock plants; 2) to determine the sensitivity of four zonal geranium cultivars to exogenous ethylene; and 3) to investigate the effectiveness of 1-MCP at preventing petal shattering in these cultivars.

\section{Materials and Methods}

Plant materials. Rooted cuttings of zonal geraniums were obtained from a commercial propagator (Busch Greenhouses, Denver). One-half of the rooted cuttings were taken from stock plants that had been treated with ethylene in the form of ethephon, to prevent flower formation and ensure maximum yield of cuttings. Ethephon applications were initiated $28 \mathrm{~d}$ after establishment of geranium stock plants and continued at $21 \mathrm{~d}$ intervals for a total of 3 applications at $400 \mathrm{mg} \cdot \mathrm{L}^{-1}$ a.i. and $32 \mathrm{~L} \cdot \mathrm{m}^{-2}$. The other half of the cuttings came from stock plants that were not treated with ethephon, but were manually pinched. All stock plants were grown in a single layer polycarbonate covered greenhouse and maintained at $17{ }^{\circ} \mathrm{C}$ night and $24^{\circ} \mathrm{C}$ day temperatures. Cuttings were harvested from both types of stock plants and rooted into a sphagnum peat-based medium. Plants grown from these rooted cuttings were used in the described experiments. These plants will be referred to as ethephon-treated and untreated plants. Cultivars used in all experiments included 'Cotton Candy', 'Fox', 'Kim', and 'Veronica'.

All rooted cuttings were transplanted into $15-\mathrm{cm}$ azalea pots filled with a commercial growing medium (Pro-Mix HP; Premier Horticulture, Red Hill, Pa.) on 23 Dec. 1998. Plants were grown in a fiberglass reinforced plastic greenhouse under natural photoperiod at $25^{\circ} \mathrm{C}$ day $/ 16^{\circ} \mathrm{C}$ night, and were fertilized at each irrigation (about twice per week) with $\mathrm{N}$ at $250 \mathrm{mg} \cdot \mathrm{L}^{-1}$ from $15 \mathrm{~N}-5 \mathrm{P}-15 \mathrm{~K}$ CalMag (The Scotts Co., Marysville, Ohio). To the surface of the media in each pot, four $g$ of slow release fertilizer $(17 \mathrm{~N}-7 \mathrm{P}-12 \mathrm{~K}$, Osmocote, The Scotts Co., Maryville, Ohio) was applied one month after transplant.

Geranium plants from each cultivar ('Cotton Candy', 'Fox', 'Kim', and 'Veronica') and stock plant treatment (ethephon-treated and untreated) were placed on four greenhouse benches in a randomized complete-block design. Two treatment combinations were randomly assigned to each block of 50 plants each. From the 50 plants, peduncle length, number of florets per inflorescence, and number of days to floret formation and visible bud color for the first six florets were determined from 10 randomly selected plants $(\mathrm{n}=10)$. Data collection was terminated 11 weeks after transplanting. General linear models analysis of the data was conducted using the SAS statistical software package version 6 (SAS Institute, Cary, N.C.).

Exposure to exogenous ethylene. To identify cultivar differences in sensitivity to ethylene, excised inflorescences were exposed to exogenous ethylene. Inflorescences were harvested and immediately placed into beakers with deionized water. Fully opened florets (with the stigmatic lobes fully reflexed) and flower buds were removed in order to obtain 
only young morphologically similar florets from each cultivar. Florets were staged by visualizing the stigma and anthers rather than the petals as described by Deneke et al. (1990). Three open florets in which the stigmatic lobes had not begun to separate and the anthers had not begun to discolor were left on each inflorescence (Deneke et al., 1990). Florets were then placed inside a sealed 24-L treatment chamber. Ethylene was injected into the chamber to a final concentration of $1.0 \mu \mathrm{L} \cdot \mathrm{L}^{-1}$. The ethylene concentration in the chambers was verified by testing a sample with a gas chromatograph equipped with a flame ionization detector and Haysep R packed column (model 3800; Varian, Walnut Creek, Calif.). Florets from all cultivars were exposed to ethylene for $1,3,10$, and $24 \mathrm{~h}$ in order to determine differences in ethylene sensitivity. Control florets were harvested the same as the treated florets, but were held in ethylene-free chambers.

After ethylene treatment, petal abscission was evaluated by holding the florets under a light stream of air for $90 \mathrm{~s}$. The number of abscised petals was recorded. Treatments consisted of a factorial arrangement of four cultivars, two stock plant treatments (ethephontreated and untreated), two ethylene concentrations $\left(0.0\right.$ and $\left.1.0 \mu \mathrm{L} \cdot \mathrm{L}^{-1}\right)$ and four ethylene treatment durations $(1,3,10$, and $24 \mathrm{~h})$. Four inflorescences with three florets each were evaluated per treatment $(n=4)$, and the experiment was conducted twice. Statistical analysis of the data was conducted as described above.

1-MCP treatment. To determine if 1-MCP could effectively prevent petal shattering with subsequent exposure to exogenous ethylene, various 1-MCP treatment concentrations and times were evaluated. Inflorescences were harvested as described above and placed in treatment chambers. 1-MCP (Ethylbloc, BioTechnologies for Horticulture, Walterboro, S.C.) was added to the chambers to three final concentrations of $0,0.1 \mu \mathrm{L} \cdot \mathrm{L}^{-1}$, or $1.0 \mu \mathrm{L} \cdot \mathrm{L}^{-1}$ for $1,3,6,12$, or $24 \mathrm{~h}$. Following 1-MCP treatment, florets were treated with 0 or 1.0 $\mu \mathrm{L} \cdot \mathrm{L}^{-1}$ ethylene for $24 \mathrm{~h}$ and petal abscission was evaluated as described above. In summary, 1-MCP experiments included five exposure durations of 1-MCP pretreatment (1, $3,6,12$, or $24 \mathrm{~h}$ ) with three 1 -MCP concentrations $\left(0,0.1\right.$, and $\left.1.0 \mu \mathrm{L} \cdot \mathrm{L}^{-1}\right)$, two ethylene treatments $\left(0\right.$ or $\left.1.0 \mu \mathrm{L} \cdot \mathrm{L}^{-1}\right)$, and four cultivars in a factorial arrangement. Only flowers from the ethephon-treated plants were used for the 1-MCP experiments because no differences in ethylene sensitivity were detected between ethephon-treated and untreated plants (see Results). Four inflorescences with three florets each were evaluated per treatment $(n=4)$, and the experiment was conducted twice. Statistical analysis of the data was conducted as described above.

\section{Results and Discussion}

Of all of the characteristics evaluated between the ethephon-treated and untreated plants, only the timing of the first floret was affected (Table 1). Ethephon treatment had no effect on the number of days to floret forma- tion and visible color of florets two through six, and had no effect on peduncle length or number of florets per inflorescence (data not shown). Among 'Kim' plants, buds were visible on the ethephon-treated plants $8 \mathrm{~d}$ earlier than on untreated plants. Ethephon treatment also resulted in a decrease in the number of days until the observation of visible color from the flower buds of 'Kim' plants. Untreated plants showed visible color in $83 \mathrm{~d}$ while treated plants showed color at $74 \mathrm{~d}$. Ethephon treatment also influenced the time to bud formation, but not color in 'Veronica'. In 'Veronica', treatment with ethephon resulted in a $4 \mathrm{~d}$ decrease in the time to the observation of the first flower bud. Among 'Cotton Candy' and 'Fox' plants, no differences in time to first bud or flower color were observed.

Ethylene's effects on flowering vary between species, but it has been well established that ethylene induces flowering in geophytes (Abeles et al., 1992). The mechanism by which ethylene stimulates flower induction in these plants is largely unknown. It has been proposed that the induction of flowering may be the result of changes in the source and sink activities, which lead to increases in the carbohydrate status of the apex

Table 1. The influence of ethephon on four cultivars of zonal geranium when applied to stock polants on days to first floret formation and days to first color after transplant of rooted cuttings.

\begin{tabular}{lcccr}
\hline \hline & \multicolumn{4}{c}{ Cultivar } \\
\cline { 2 - 5 } Ethephon & Cotton Candy & Fox & Kim & Veronica \\
\hline \multirow{2}{*}{ Treated } & ----- & Days to first floret formation ------ \\
Nontreated & $50.5 \mathrm{a}^{2}$ & $52.2 \mathrm{a}$ & $52.4 \mathrm{~b}$ & $50.5 \mathrm{~b}$ \\
& $52.4 \mathrm{a}$ & $51.3 \mathrm{a}$ & $60.6 \mathrm{a}$ & $54.9 \mathrm{a}$ \\
Treated & ------ & Days to first color ---- & --- \\
Nontreated & $65.0 \mathrm{a}$ & $69.8 \mathrm{a}$ & $74.1 \mathrm{~b}$ & $68.8 \mathrm{a}$ \\
\hline
\end{tabular}

${ }^{2}$ Means in columns followed by the same letter were not different as determined by the Fisher's least significant difference test at $P \leq 0.05$.

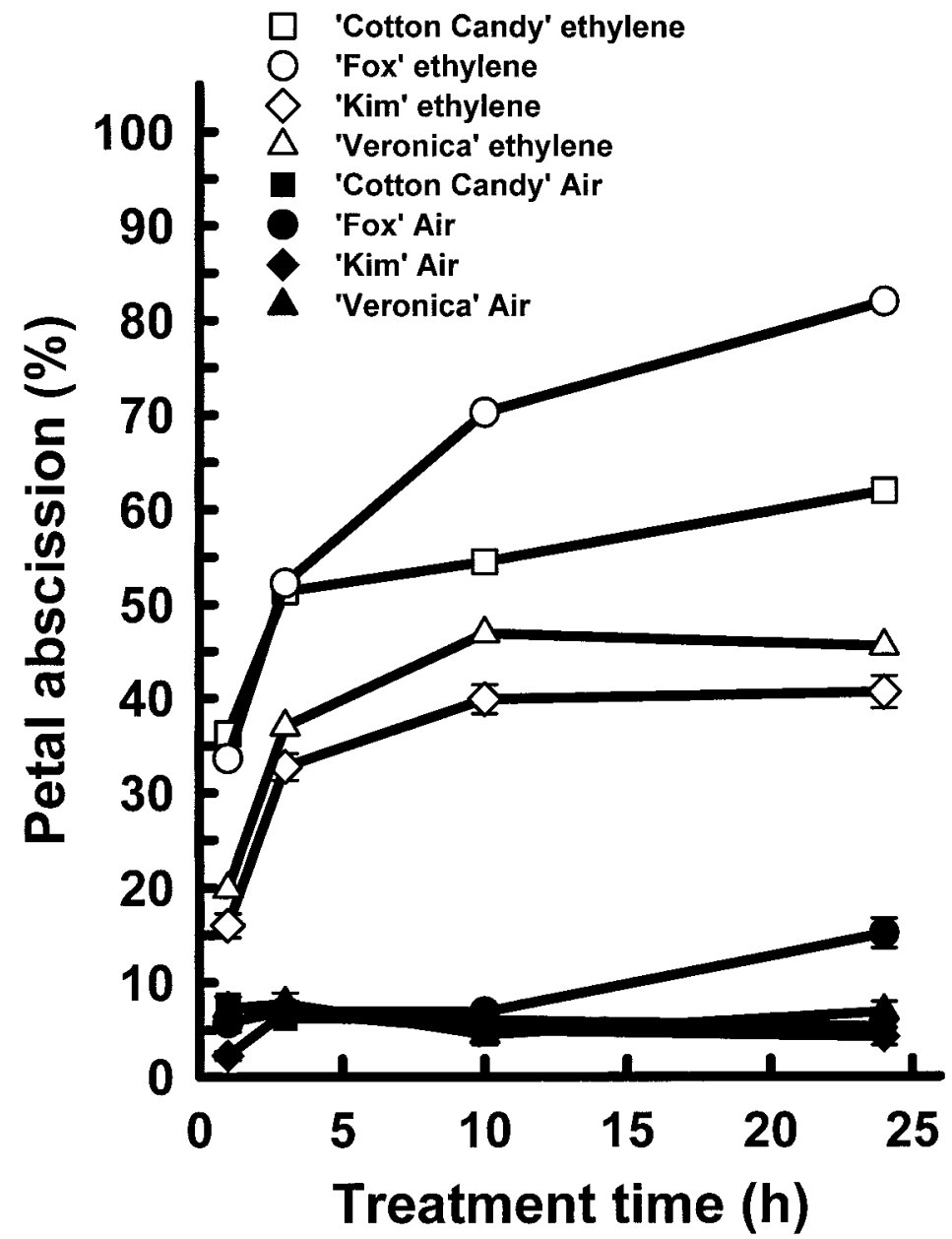

Fig. 1. Ethylene sensitivity of 'Cotton Candy', 'Fox', 'Kim', and 'Veronica' geraniums. Florets were treated with $1.0 \mu \mathrm{L} \cdot \mathrm{L}^{-1}$ ethylene in a $24-\mathrm{L}$ chamber. Controls were held in a chamber with ethylene free air. The percentage of petal abscission was calculated after various exposure times. Each time point represents the average percentage of abscission value for four inflorescences $\pm \mathrm{SE}$. 
(Sachs, 1977). In Triteleia laxa, treatment of corms with exogenous ethylene accelerates the growth of the meristematic dome, and accelerates flower induction (Han et al., 1990). In both T. laxa and Dutch iris, ethylene treatment results in longer and wider leaves, thereby increasing photosynthesis (Han et al., 1990; Imanishi et al., 1994). In geranium, which are day neutral, the leaf area and photosynthetic capacity of the first leaves determines the rate of floral initiation of the first flower (Dole and Wilkins, 1999). The accelerated flower induction in 'Kim' and 'Veronica' geraniums may therefore be the result of ethylene's effects on enhancing vegetative growth and therefore photosynthetic capacity of the plant.

Ethylene sensitivity. All cultivars responded to the application of exogenous ethylene with increased petal abscission (Fig. 1). The sensitivity to ethylene varied among cultivars with 'Kim' being the least sensitive followed by 'Veronica' and 'Cotton Candy'. 'Fox' was the most sensitive to ethylene, abscising the most petals following all treatments. Previous reports have indicated vary- ing sensitivity to ethylene among cultivars of geranium (Clark et al., 2001; Deneke et al., 1990). Increased rates of abscission over controls were observed in all cultivars following $1 \mathrm{~h}$ of exposure to $1.0 \mathrm{~mL} \cdot \mathrm{L}^{-1}$ ethylene. In geranium, petal abscission rates depend on both the ethylene concentration and treatment times (Evensen, 1991). Geraniums have been reported to be among one of the most ethylene-sensitive species. Petal abscission in both $P . \times$ domesticum Bailey and $P . \times$ hortorum has been reported to occur within $1 \mathrm{~h}$ of treatment with $1.0 \mu \mathrm{L} \cdot \mathrm{L}^{-1}$ or less ethylene (Clark et al., 1997; Deneke et al., 1990; Evensen, 1991; Evensen et al., 1993). The abscission of Geranium robertianum petals was reported to occur after $2.25 \mathrm{~h}$ of ethylene exposure (Sexton et al., 1983). There was no difference in ethylene sensitivity as measured by percent petal abscission, between ethephon-treated and untreated plants (data not shown).

1-MCP treatment. Pretreatment of geranium inflorescence with the ethylene action inhibitor 1-MCP was effective at reducing petal abscission in all cultivars (Figs. 2-5).
Treatment with $1-\mathrm{MCP}$ at $0.1 \mu \mathrm{L} \cdot \mathrm{L}^{-1}$ for $1 \mathrm{~h}$ was effective at reducing petal abscission rates following ethylene treatment compared to control flowers held in air in all cultivars except Fox. In 'Fox', which was the most ethylene-sensitive cultivar, higher dosages of $1-\mathrm{MCP}$ were required to reduce the percent petal abscission to control rates (Fig. 3). Even though not as effective on 'Fox', treatment with 0.1 or $1.0 \mu \mathrm{L} \cdot \mathrm{L}^{-1} 1-\mathrm{MCP}$ for $6 \mathrm{~h}$ or more reduced petal abscission to control rates. In potted flowering begonias, roses, and kalanchoes, treatment with 1-MCP did not enhance the display life of plants unless they were treated with exogenous ethylene (Serek et al., 1994). In our studies, 1-MCP decreased rates of petal abscission in flowers held in air compared to those nontreated flowers held in air (Figs. 2-5). This is especially apparent in flowers of 'Fox' (Fig. 3). Our data demonstrate that $1-\mathrm{MCP}$ at $1.0 \mu \mathrm{L} \cdot \mathrm{L}^{-1}$ for $6 \mathrm{~h}$ would be an effective treatment for all four cultivars studied. Serek et al. (1994) previously reported that 1-MCP was as effective as STS in preventing petal and bud abscission and flower senescence in begonia, miniature roses, and

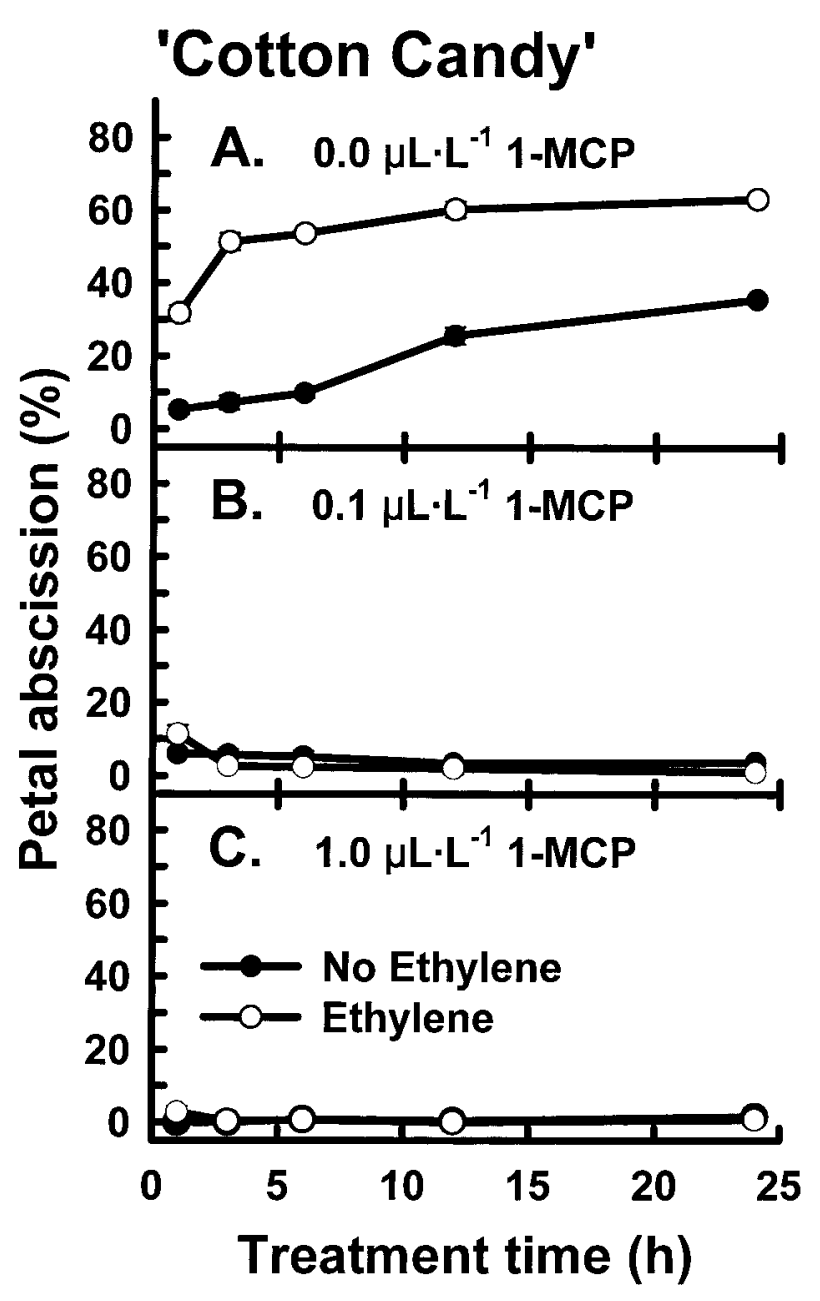

Fig. 2. 'Cotton Candy' florets were pretreated with (A) $0 \mu \mathrm{L} \cdot \mathrm{L}^{-1} 1-\mathrm{MCP},(\mathbf{B})$ $0.1 \mu \mathrm{L} \cdot \mathrm{L}^{-1} 1-\mathrm{MCP}$, and (C) $1.0 \mathrm{~mL} \cdot \mathrm{L}^{-1} 1-\mathrm{MCP}$ in $24-\mathrm{L}$ treatment chambers for various times. Following 1-MCP treatment florets were exposed to 1.0 $\mu \mathrm{LL}^{-1}$ ethylene or air. After $24 \mathrm{~h}$, percentage of petal abscission was determined. Each time point represents the average value for four inflorescences $\pm \mathrm{SE}$.
'Fox'

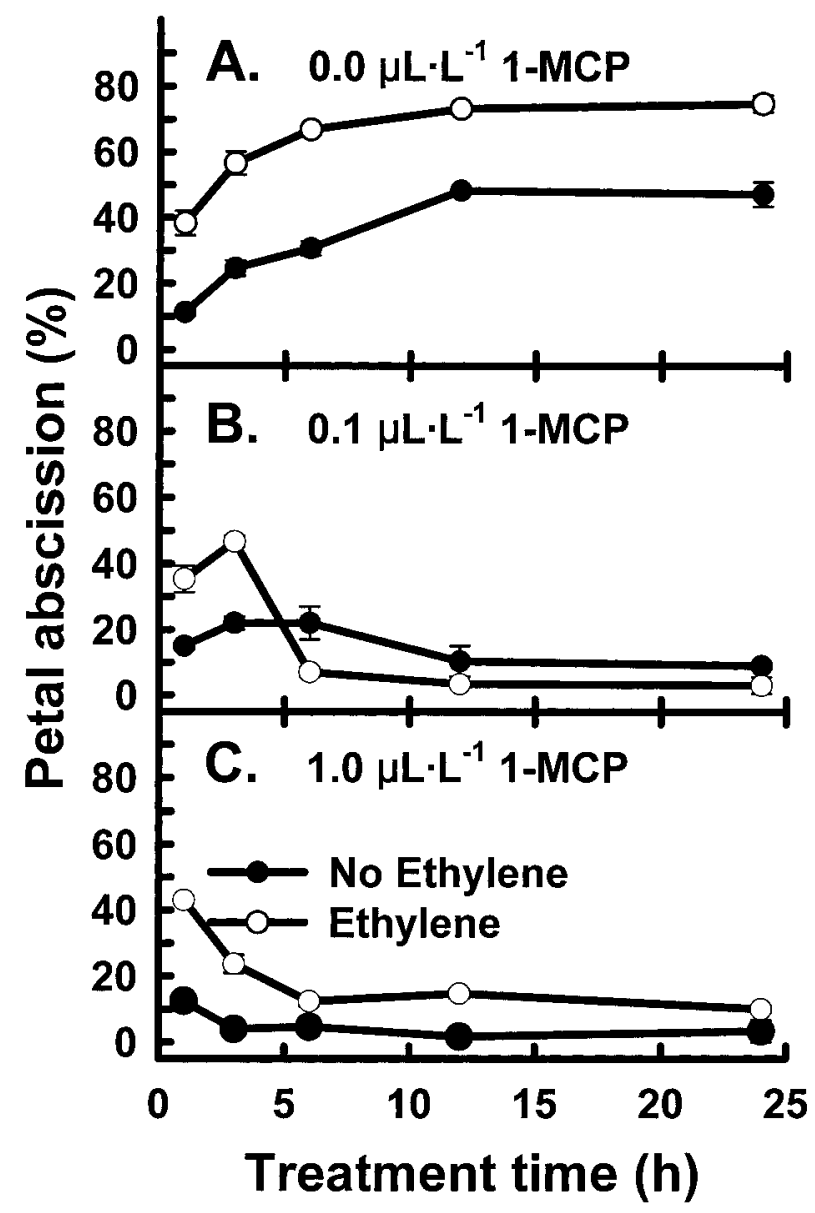

Fig. 3. 'Fox' florets were pretreated with (A) $0 \mu \mathrm{L} \cdot \mathrm{L}^{-1} 1-\mathrm{MCP},(\mathbf{B}) 0.1 \mu \mathrm{L} \cdot \mathrm{L}^{-1}$ 1-MCP, and $(\mathbf{C}) 1.0 \mu \mathrm{L} \cdot \mathrm{L}^{-1} 1-\mathrm{MCP}$ in $24-\mathrm{L}$ treatment chambers for various times. Following 1-MCP treatment florets were exposed to $1.0 \mu \mathrm{L} \cdot \mathrm{L}^{-1}$ ethylene or air. After $24 \mathrm{~h}$, percentage of petal abscission was determined. Each time point represents the average value for four inflorescences \pm SE. 


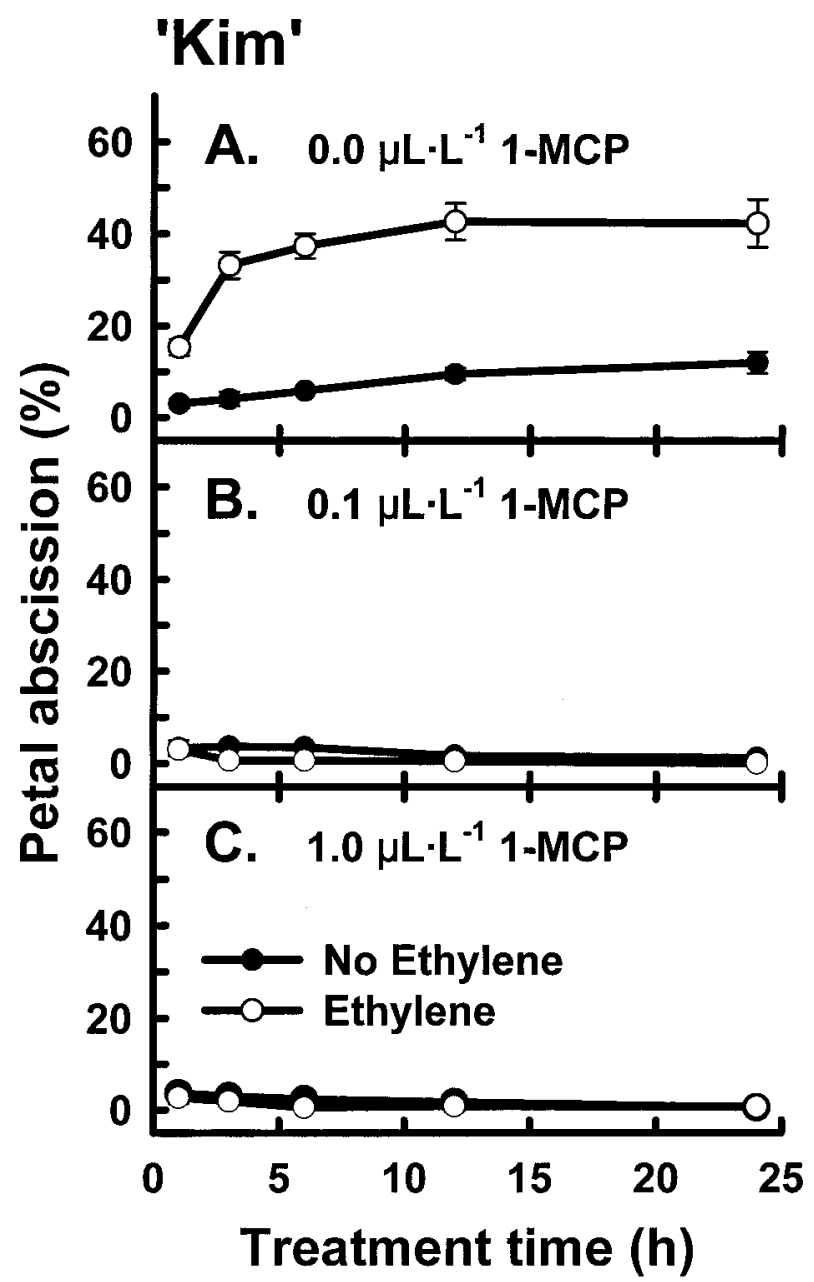

Fig. 4. 'Kim' florets were pretreated with (A) $0 \mu \mathrm{L} \cdot \mathrm{L}^{-1} 1-\mathrm{MCP}$, (B) 0.1 $\mu \mathrm{L} \cdot \mathrm{L}^{-1} 1-\mathrm{MCP}$, and (C) $1.0 \mu \mathrm{L} \cdot \mathrm{L}^{-1} 1-\mathrm{MCP}$ in $24-\mathrm{L}$ treatment chambers for various times. Following 1-MCP treatment florets were exposed to $1.0 \mu \mathrm{L} \cdot \mathrm{L}^{-1}$ ethylene or air. After $24 \mathrm{~h}$, percentage of petal abscission was determined. Each time point represents the average value for four inflorescences $\pm \mathrm{SE}$.
'Veronica'

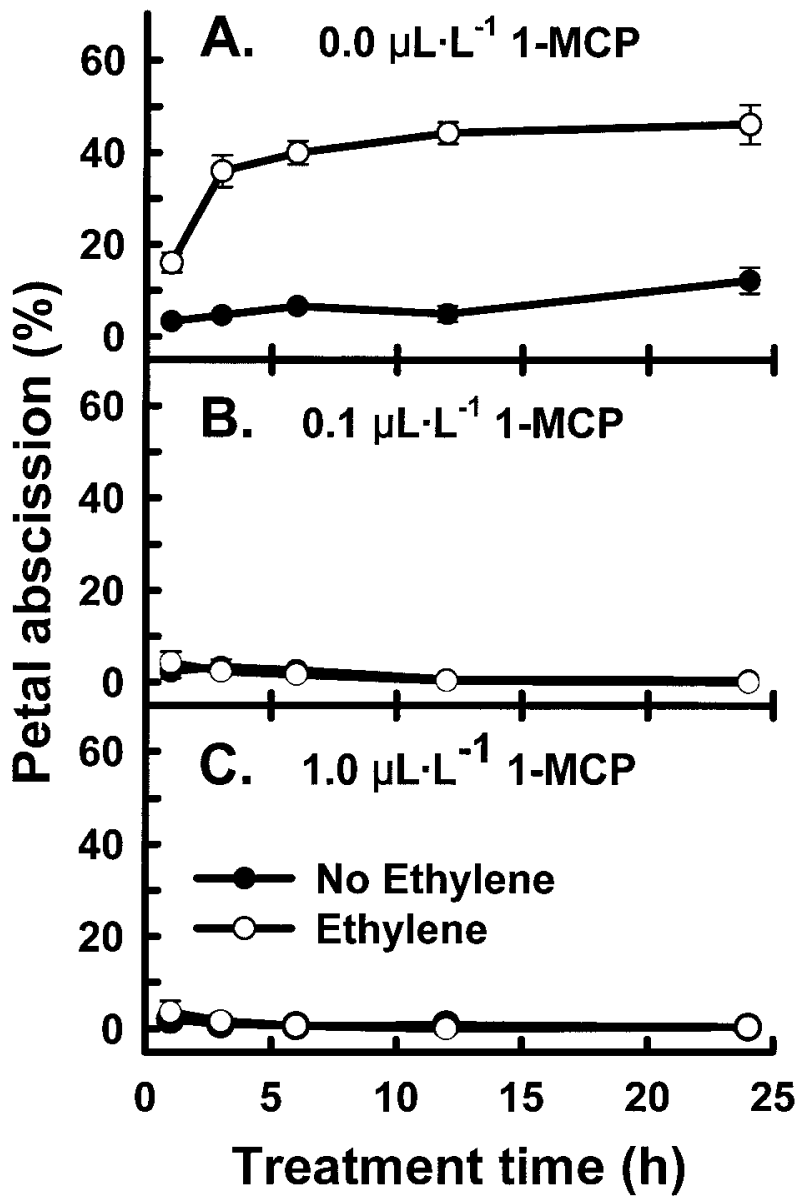

Fig. 5. 'Veronica' florets were pretreated with (A) $0 \mu \mathrm{L} \cdot \mathrm{L}^{-1} 1-\mathrm{MCP},(\mathbf{B})$ $0.1 \mu \mathrm{L} \cdot \mathrm{L}^{-1} 1-\mathrm{MCP}$, and $(\mathbf{C}) 1.0 \mu \mathrm{L} \cdot \mathrm{L}^{-1} 1-\mathrm{MCP}$ in $24-\mathrm{L}$ treatment chambers for various times. Following 1-MCP treatment florets were exposed to $1.0 \mu \mathrm{L} \cdot \mathrm{L}^{-1}$ ethylene or air. After $24 \mathrm{~h}$, percentage of petal abscission was determined. Each time point represents the average value for four inflorescences \pm SE. kalanchoe. The plants in these studies were treated with 6 to $20 \mathrm{~nL} \cdot \mathrm{L}^{-1} 1-\mathrm{MCP}$ gas for 6 h. Preliminary experiments with 10 and 50 $\mathrm{nL} \cdot \mathrm{L}^{-1} 1-\mathrm{MCP}$ were not effective at reducing petal abscission when geranium florets were exposed to ethylene (data not shown). The concentrations used in the experiments presented in this paper were chosen because they are the labeled rates indicated for 1-MCP as marketed to the floral trade. Geraniums are more sensitive to ethylene and as such may require a higher dosage of $1-\mathrm{MCP}$ to protect them from ethylene damage.

Under the criteria we used to evaluate floret sensitivity to ethylene (percentage of petal abscission), it did not appear that stock plant treatment with ethephon predisposed plants to higher rates of petal abscission when exposed to ethylene. Our results support previous experiments indicating that zonal geraniums are sensitive to ethylene. All four cultivars exhibited increased petal abscission over controls within $1 \mathrm{~h}$ of exposure to ethylene. The ethylene action inhibitor, 1-MCP, proved effective at decreasing rates of petal abscission after exposure to ethylene. Only a small percentage of petals from 1-MCPtreated florets abscised, leaving enough petals to ensure that a saleable product would reach the market if the plants were exposed to ethylene during shipping. While 1-MCP will protect most cultivars of geranium during a 24-h period of exposure to ethylene, additional studies are needed to determine how long a single 1-MCP treatment is effective.

\section{Literature Cited}

Abeles, F.B., P.W. Morgan, and M.E. Saltveit, Jr. 1992. Ethylene in plant biology. $2^{\text {nd }} e d$. Academic, San Diego.

Cameron, A.C. and M.S. Reid. 1983. Use of silver thiosulfate to prevent flower abscission from potted plants. Scientia Hort. 19:373-378.

Clark, D.G., C. Dervinis, J.E. Barrett, and T.A. Nell. 2001. Using a seedling hypocotyl elongation assay as a genetic screen for ethylene sensitivity of seedling geranium cultivars. HortTechnology 11:297-302.

Clark, D.G., C. Richards, Z. Hilioti, S. Lind-Iversen, and K. Brown. 1997. Effect of pollination on accumulation of ACC synthase and ACC oxidase transcripts, ethylene production and flower petal abscission in geranium (Pelargonium $\times$ hortorum L.H. Bailey). Plant Mol. Biol. 34:855-865.

Deneke, C.F., K.B. Evensen, and R. Craig. 1990. Regulation of petal abscission in Pelargonium $\times$ domesticum. HortScience 25:937940.

Dole J.M. and H.F. Wilkins. 1999. Floriculture: Principles and species. Prentice Hall, New Jersey.

Evensen, K.B. 1991. Ethylene responsiveness changes in Pelargonium $\times$ domesticum florets. Physiol. Plant. 82:409-412.

Evensen, K., A.M. Page, and A.D. Stead. 1993. Anatomy of ethylene-induced petal abscission in Pelargonium $\times$ hortorum. Ann. of Bot. 71:559-566.

Han, S.S., A.H. Halevy, R.M. Sachs, and M.S Reid. 1990. Enhancement of growth and flowering of Triteleia laxa by ethylene. J. Amer. Soc. Hort. Sci. 115:482-486.

Hausbeck, M.K., C.T. Stephens, and R.D. Heins. 1987. Variations in resistance of geraniums to Phythium ultimum in the presence or absence of silver thiosulfate. HortScience. 22:940-943. 
Imanishi, H., A.H. Halevy, A.M. Kofranek, S Han, and M.S. Reid. 1994. Respiratory and carbohydrate changes during ethylene-mediated flower induction in Dutch iris. Scientia Hort. 58:275-284.

Nell, T.A. 1993. Flowering potted plants: Prolonging shelf performance. Ball Publishing, Batavia, Ill.

O’Donovan E.J. 1993. Stock plants. In: J.W. White (ed.). Geraniums IV. Ball Publishing, Geneva, Ill.

Oglevee, B. 1998. Pelargonium $\times$ hortorum. In: V.
Ball (ed.). Ball Redbook. 16 ${ }^{\text {th }}$ edition. Ball Publishing, Batavia, Ill.

Sachs, R.M. 1977. Nutrient diversion. A hypothesis to explain the chemical control of flowering. HortScience. 12:220-222.

SAS Institute. 1985. SAS/STAT guide for personal computers. Version 6. SAS Inst., Cary, N.C.

Serek, M., E.C. Sisler, and M.S. Reid. 1994. Novel gaseous ethylene binding inhibitor prevents ethylene effects on potted flowering plants. J. Amer. Soc. Hort. Sci. 119:1230-1233.
Serek, M., E.C. Sisler, and M.S. Reid. 1995. Effect of 1-MCP on the vaselife and ethylene response of cut flowers. Plant Growth Regulat. 16:93-97.

Sexton, R., W.A. Struthers, and L.N. Lewis. 1983. Some observations on the very rapid abscission of the petals of Geranium robertianum L. Protoplasma 116:179-186.

Sisler, E.C., E. Dupille, and M. Serek. 1996. Effect of 1-methylcyclopropene and methylenecyclopropane on ethylene binding and ethylene action on cut carnations. Plant Growth Regulat. 18:79-86. 